\title{
A Practical Guide for Policy Analysis on Affirmative Action Policy
}

\author{
Robert Knox \\ Texas Southern University \\ Michael O. Adams \\ Texas Southern University \\ Samuel Arungwa \\ Utah State University \\ Gbolahan S. Osho \\ Prairie A\&M University
}

Received: June 17, 2020 Accepted: July 30, 2020 Online published: August 9, 2020

doi:10.5296/jpag.v10i3.17200～URL: https://doi.org/10.5296/jpag.v10i3.17200

\begin{abstract}
The Act established, in pursuit of meeting it is proclamation, the Equal Employment Opportunity Commission. However, most employers did not abide by the act, and continued to discriminate against minorities and women with lower wages or refuse to hire them. If a minority reported the incident, usually there was nothing done to the employer. The United States office the Civil Rights Commission describes affirmative action as covering every degree of single termination of a discriminatory practice, that allows for race, national origin, sex, or disability, laterally with other benchmarks, and that embraced to offer prospects to a class of persons with historically or actually been deprived of those prospects, and to preclude repetition of discrimination in the future.
\end{abstract}

Keywords: affirmative action, policy, ACT, SAT scores, The University of Michigan

\section{Introduction}

The 1961 executive order signed by President John F. Kennedy allowed affirmative action for 
the first time by initiating federal contractors to include affirmative action to guarantee that applicants are treated the same regardless of their race, color, religion, sex, or national origin (inmotionmagazine). President Kennedy new policy was inspired by the nation of Zeitgeist of more "civil rights and more gender equality. In correlation to his order, in "1964 the Civil Rights Act extended Kennedy's order to non-governmental contractors, making nearly all employment discrimination illegal. The Act established, in pursuit of meeting it is proclamation, the Equal Employment Opportunity Commission. However, most employers did not abide by the act, and continued to discriminate against minorities and women with lower wages or refuse to hire them. If a minority reported the incident, usually there was nothing done to the employer.

In 1967 President Lyndon B. Johnson issued E.O. 11246, demanding all federal administration contractors and subcontractors to allow affirmative action to increase job prospects for minorities. Therefore, the government created the Office of Federal Contract Compliance (OFCC) within the Department of Labor to oversee the directive (inmotionmagazine). Furthermore, in 1967 the administration modified E.O. 11246 to involve affirmative action for women. Hence, all federal contractors are currently obligated to endeavor to increase employment opportunity for women and minorities (inmotionmagazine).

The United States Civil Rights Commission defines affirmative action as "encompassing any measure, which beyond single termination of a discriminatory practice, which permits the consideration of race, national origin, sex, or disability, along with other criteria, and which is adopted to provide opportunity to a class of individuals who have either historically or actually been denied those opportunities, and to prevent recurrence of discrimination in the future." Since the beginning, Affirmative Action Policies have sparked many debates about the disadvantages and advantages of this policy.

Proponents of this policy argue that the United States need policies such as affirmative action to balance out opportunity for everyone. Before the Affirmative Action Policy, women and minorities were deprived of freedom and discriminated against. Opponents of affirmative action know that America is not a color-blind society, because large gaps still existing in the work place and enrollment in school. Proponents would agreed, some minorities as women do not lack the mental capabilities of going to good universities or getting higher paying jobs. Hence, the primary objective of this paper is to review and provide a practical guide for policy analysis on affirmative action policy. The reason that these groups, statistically speaking, have lower SAT scores and do not have as many top jobs as white males in the United States do, is because of this lingering social outlook (nyu.edu). Discrimination in hiring process is equally difficult to classify and regulate, this contributes to affirmative action's problematic natures.

\section{Literature Review}

Affirmative Action differs from state to state and in 1996 California voters approved Proposition 209 which ended affirmative action polices in the state public education. As a result, minority enrollment in the University of California system dropped to a staggering low with an 18\% drop in African American enrollment and 7\% drop in Hispanics." (nyu.edu). It is 
hard to determine the effects of affirmative action in the job market and higher education. In the case of the University of California, it appears that the affirmative action policy had a big impact on enrollment for minorities and revenue generated.

However, with the $25 \%$ drop in enrollment of minorities, the researcher did not state if the enrollment of white students increased or did the enrollment of other minority students increased, such as Japanese, Chinese, Korean and other nationality. Or did the University of California accept minority students just based on affirmation action and not on their ACT, SAT scores and transcripts from other schools and universities.

In the state of Texas it was easier to see the effects of affirmative action acceptance rates. For example, "In 1995 the University of Rice had an acceptance rate for African Americans of $51.7 \%$ while that of whites was closer to $25 \%$." This increase in enrollment for African American was due to the Texas Legislature banning affirmative action policies in higher educational facilities. Affirmative action does actually send more minority students to college. Most people don't realize this. Advocates mention affirmative action and the importance of college together so often that we are bound to think there is a connection.

Plus, affirmative action does not guarantee minority students will pass college classes or graduate from college. "The reason that more minority students do not get degrees has nothing to do with competitive admissions. Rather, too many of them leave high school without the bare minimum credentials necessary to attend any four-year school, or not. Freshman must be college ready, they must be literate, have their high school diploma and they must have taken certain minimum coursework (Cato Policy Report). However, "recent sociological research demonstrates that preferences hurt campus race relationships. Worse, they harm minority student performance by activating fears of confirming negative group stereotypes, lowering grades and reducing college completion rates among preferred students (Affirmative action myth).

But no matter how often we hear the important of a college education and affirmative action in the same breath, the one still does not affect the other." (Cato Policy Report) According to Jay Greene of Manhattan Institute stated 20 percent of black students and 16 percent of Hispanic students leave high school ready to go to college. Minority under-representation in the college environment is thus the result of public schools failure to prepare minority students (Cato Policy Report). Studies have shown that expertise, not qualifications, could close socioeconomic gaps between Caucasians and minority groups. Therefore, policymakers have a duty to end the destructive practice of racial partialities in university admission decisions. Rather, it is important to implement policies and measures that would close the critical skills gap such as school choice reforms and establishing upper academic prospects for students of all backgrounds (Affirmative action myth).

Over the past three decades minorities and women have made some economic progress. Before the Civil Rights Bill was signed and made into law, "the median black male worker earned only $60 \%$ as much as the median white male worker; by 1993, the median black male earned $74 \%$ as much as the median white male. The male-female wage gap has also narrowed since the 1960's median female earnings relative to median male earnings rose from about 
$60 \%$ during the 1960 s to $72 \%$ in 1993 (Conncoll. edu).

Due to past discrimination, affirmative action tried to bring up the representation of certain racial or sex groups in certain fields of work and study where they are usually under-representation. It is argued that people of a certain race and sex has a socioeconomic disadvantage due to oppression, racism and sexism. The critics of affirmative action states affirmative action perpetuate discrimination while claiming to bring equality to university admissions and job hiring. Critics think this policy helps some people while hurting others. For example, Blacks, Hispanics, and Native Americans benefit the most from affirmative action. Their history with the United States is rifle with discrimination and hardship. Yet, Asians, another minority, are hurt by this policy along with whites' particularly poor whites.

Critics also claim that it is government-sanctioned racism and it is demeaning toward members of minority groups by saying that they are not capable enough of being judged on their own merit. Another criticism is that it does not bring into account socioeconomic discrimination. A college may take middle class members of a minority group over a better qualified working class white male. Therefore, middle class minorities who have more resources and opportunities at their disposal are favored over the working poor who are not minority, usually poor whites." (nyu.edu) Now, there are some opponents of affirmative action, and may question if this policy is the right way to correct the past and present injustice. However, "supporters do not believe that being black is a morally relevant feature which deserves discriminatory behavior; but they do believe that injustices based on that mistake should be compensated. Being black is only morally relevant in that it was used to justify the original sin.

Affirmative action based on retribution often attempts often attempt to correct historic by repaying the decedents of those who have been treated unjustly. Typically this means compensating contemporary African and Native Americans. However, critics of retributive affirmative action object to the principle of requiring innocent individuals in the present generation to repay the decedents of those who were victims of injustice committed by previous generations. Justice, they argue, entails the reconciliation of the actual victims and perpetrators, not their decedents.

In order to change the patterns of unequal distribution, some defenders of affirmative action want to require companies to hire a certain number of women and minorities. This is called a quota. Many of the best jobs require many years of education. That's way many affirmative action programs target educational opportunity. Some African American, say that they are denied access to an equal education because urban public schools are inferior and under-funded, while white suburban schools are superior and funded lavishly. Some critics of affirmative action admit that we ought to improve inner-city schools, but not lower the college entry standards for African Americans (inside.msj.edu).

How, if the state legislatures were to fund each school district with the same amount of money and technology, most minority students would be better prepared for College. Plus, most of the minority schools lack the proper technology to compete with other richer school districts. "This is a failed process that affirmation action cannot help minority (Cato Policy 
Report).

Libertarians are characterizes as the main opponents of affirmation action who either favor distribution or redistribution based on merit. The chief criticism of distribution based on merit or meritocracy, is that it invariably leads to social stratification, and social classes. Other critics point out that well-intentioned system of merit often harbor covert racism, sexism and other forms of partiality. Although we might intend to devise impartial procedures for distributing a merit scholarship, to those procedures might actually end up rewarding entire classes (or group) of individuals. That's why many question the validity of I.Q test, ACTs, SAT and Civil Service Exam as impartial measures of merit.

Some defenders of meritocracy argues that merit is, in fact, often naturally associated with age, sex, and race and that the natural attributes of women and African Americans disadvantage them in the competition for resources. Most critics against affirmative action believe that white males are more born with an advantage to compete and lead! The problem is that most of the higher paying jobs are held by white males and they will hire anyone white male, before a minority (inside.msj.edu). Plus, as long as white males and females are in these higher positions society will be faced with the question of affirmative actions in the workplace. Affirmative Action is not based upon the assumptions that white males as white. In fact, Affirmative Action programs are justified by the need to counteract the continuing effects of such discrimination against peoples of color or women. These effects sometimes operate openly but most often in very subtle ways"(wku.edu).

One of the advantages of affirmative action, it attempts to provides "diversity in the work place and educational system that might not otherwise be there. It also attempts to address a very complex social problem that exits in the U.S. It is hard to separate socioeconomic status with that of race because the two are heavily intertwined with one another. For a white family, the median income is about $\$ 44,000$ a year while a black family will make about $\$ 24,000$ and a Hispanic family $\$ 33,000$. Blacks make up about 13.8 and Hispanics 11.1 percent of the total labor force and are only represent 6.5 and 5 percent of upper management while whites make up about 69.9 percent of the labor force and about 84.5 percent at the executive level. Also, those of minority are more likely to be born into poverty then those who are white; 29 percent of Hispanic kids and 33 percent of black kids and only 10 percent of white kids are born below the poverty line and while Hispanics and Blacks fall far below their white counterparts in economic and educational achievements" (nyu.edu).

The issue of affirmative action is most commonly associated with education as expressed by the high number of court cases that deal with affirmative action and education." (nyu.edu) In 1997 Jennifer Gratz and Patrick Hamacher filed lawsuit against the University of Michigan alleging that the University's use "of racial preference in undergraduate admissions violated the Equal Protection Clause of the Fourteenth Amendment, Title VI of the Civil Rights Act of 1964, and 42 U.S.C. 1981. They sought compensatory and punitive damages for past violations, declaratory relief finding that respondents violated their rights to nondiscriminatory treatment, an injunction prohibiting respondents from continuing to discrimination on the basis of race and an order requiring the LS\&A to offer Hamacher 
admission as a transfer student" (vpcomm.umich).

The LS\&A program "is the flagship undergraduate institution of the University of

Michigan, one of the nation's leading public institutions higher education. LS\&A seeks to provide an education that will prepare its students to excel in their chosen vocations and to participate as active citizen in our democracy. The University of Michigan enjoys a first-rate reputation for educational excellence and attracts nearly two-thirds of its applicants and a third of its entering class from outside Michigan, including all 50 states and over 80 nations (U of M case).

The District Court granted petitioners' motion to certify a class consisting of individuals who applied for and were denied admission to the LS\&A for academic year 1995 and forward and who are members of racial or ethnic groups that respondents treated less favorably on the basis of race. Hamacher, claim challenged the University of Michigan LS\&A Admission Program based on racial discrimination on a class-wide basis (vpcomm.umich).

In 1997, when the petitioners filed their lawsuit, LS\&A enrolled only 3,958 first-year students from more than 13, 000 applicants. LS\&A is a selective institution. It receives many more applicants than it has available spaces. Many of the applicants that apply are fully qualified to attend LS\&A. It is known that LS\&A will only accept qualified students applicants. Thus, in selecting students from this competitive pool, admission officers must decide which set of applicants, considered individually and collectively, will take fullest advantage of what the college has to offer. In 1995, when Gratz applied to LS\&A, more than 1,400 white and Asian-American students with lower adjusted high school GPAs or test score than hers were admitted, while more than 2,000 white and Asia-American students with higher adjusted GPAs or test scores were rejected." (U of M case)

\section{Experiential Reports}

According to the University staff, "there is a common misperception, especially when viewed from a single applicant's isolated perspective that offers of admission are entitlements based on grades and test scores. With a finite number of available spaces many qualified applicants must be rejected despite their strong credentials." (U of M case) However, in the petition filed by Gratz and Hamacher, Judge Powell stated, The LS\&A “admission guidelines for 1995 through 1998 operated as the functional equivalent of a quota running afoul and thus granting petitioners' summary judgement with respect to respondents' admissions programs for those years (vpcomm.umich).

In 1991, Mr. Knox a co-author of this paper applied to the University of Michigan and was rejected. The University of Michigan did not give me any reason why my application was denied. He then applied to private school called Saginaw Valley Stated College. As he was attending school, three weeks into the semester, he received a letter from the $\mathrm{U}$ of $\mathrm{M}$ stating that he was now accepted and come to orientation. He did not understand why he was rejected the first time and why did they change their mind. He withdrew from Saginaw Valley and re-enroll into the University of Michigan. While attending school there were times when he was the only black male in class or the only black person in class. 
When he graduated in 1994 out of a class of 300 students, there was only 5 black male receiving a degree he was one of the five that afternoon. After he received my degree, my father asked me "Why wasn't more black male graduating form Michigan." He was told that black males had a hard time being accepted into the University. The University states, "It considers a broadly diverse student body an integral component of its mission because such diversity increases the intellectual vitality of its education, scholarship, service and communal life. The admissions office at the "University of Michigan task is to assemble a class that will collectively create an environment on our campus that is diverse in many respects and that will foster the most vibrant educational atmosphere.

University official states, without the existence of significant numbers of minority students on the university campus, these collaborations and the academic benefits they nurture cannot take place. Important racial and ethnic diversity in a wide variety of college environments are essential both to guarantee that minority students do not feel insulated and forced to account for their racial or ethnic group and to remove labels by consenting students to view each other as individuals ( $\mathrm{U}$ of $\mathrm{M}$ case).

LS\&A attempts to enroll a largely diverse student population and concurrently upholding its pledge to educational excellence. Many people could understand that having a diverse student body on campus and having a wide variety of minority students. But, when an applicant was attending the University of Michigan there appeared to be one black student per every two white students. A lot of the minority students knew that the University was monitoring the progress of the minority students. The University of Michigan is aware, to achieve the benefits of diversity "LS\&A purses means other than considering race in admissions. LS\&A vigorously recruits minority students with competitive academic credentials, both to maximize the number of such students who apply and to increase the percentage of those admitted who choose to enroll." (U of M) However, Gratz stated in the petition to the court, suggested that the University has a policy of admitting all qualified minority applicants is incorrect.

According to Gratz, no such policies exit. "The fact that virtually all qualified minority applicants are admitted is simply a description of admissions outcomes given that there are few such applicants." Moreover, although prior versions LS\&A's admissions guidelines encourage counselors to admit qualified minority candidates as qualified minority candidates as quickly as possible, without postponing decision on their applications, it is undisputed that the guidelines from 1999 forward discontinued this practice (U of M case).

Due to the University's use of race in its current freshman admissions policy is not narrowly tailored to achieve respondents' assert interest in diversity, the policy violates the Equal Protection Clause. For the reason set forth in Grutter vs. Bollinger, post, at 15-21, the Court has today rejected petitioners' argument that diversity cannot constitute a compelling state interest. The Court found that the current policy, which automatically distributes 20 points, or one-fifth of the points needed to guarantee admission, to every single underrepresented minority applicant solely because o race, is not narrowly tailor to achieve educational diversity. In Bakke, Justice Powell explained his view that it would be permissible for a 
university to employ an admissions program in which race or ethnic background may be deemed a plus in a particular applicant's file. 438 U.S. at 317. Judge Powell emphasized, the importance of considering each particular applicant as an individual, assessing all of the qualities that individual possesses, and in turn, evaluating that individual's ability to contribute to the unique setting of higher education (vpcomm.umich).

The fact that LS\&A has created the possibility of an applicant's file being flagged for individual consideration only emphasizes the flaws of the University's system as a whole when compared to that described by Justice Powell. The record does not reveal precisely how many applicants are flagged, but it is undisputed that such consideration is the exception and not the rule in the LS\&A program. This individualized review is only provided after admissions counselors automatically distribute the University's version of a plus that makes race a decisive factor for virtually every minimally qualified underrepresented minority applicant"(vpcomm.umich). The court forbidden the respondent suggestion that the size of applicants the university received and information making it impractical for the University LS\&A program to use the admission system upheld today in Gutter. The court states "the fact that the implementation of a program capable of providing individual consideration might present administrative challenges does not render constitutional an otherwise problematic system" (vpcomm.umich).

However, nothing in Judge Powell opinion suggested that the $U$ of $M$ could employ or use any method to increase the diversity without regard to the limits imposed by strict scrutiny. During the proceedings "Hamacher indicated that he attended to apply to transfer it the LS\&A discriminatory admissions system is eliminated, he has since graduated from Michigan State University. In the case of Gratz, Duderstadt was the president of the University of Michigan during the time her application was under consideration. He has been sued in his individual capacity. "Bollinger was the president of the University when Hamanher applied for admission. He was originally sued in both his individual and official capacities, but he is no longer the president of the University" (vpcomm.umich).

The District Court approved petitioners' motion for class authorization after concluding that a class action was suitable pursuant to Federal Rule of Civil Procedure. The registered class action contained of those persons who put in for and were not approved admissions to the Colleges in the University of Michigan for all academic years from 1995 and belong to those racial or ethnic groups comprising Caucasian that defendants considered not favorably due to their race in deliberating their admissions requests.

In the case of Hanacher, these assertions that the District Court established to contest a practice of racial discrimination ubiquitously applied on a general basis, was labeled as the class representative. The court also approved petitioners' motion to separate the proceeding into liability and damages levels. The liability level was to define whether [respondents] apply race as elements in admissions assessments infringe the Equal protection Clause of the Fourteenth Amendment to the Constitution.

The University has transformed its admissions parameters several times during the period pertinent to the lawsuit, and it was reviewed that the most noteworthy of these modifications 
are: i. the University's Office of Undergraduate Admissions administers the LS\&A admissions process. ii. To adequately uphold consistency in the evaluation of the huge volume of applicants received, they must apply written guidelines for each academic year.

The University admissions counselors must make admissions decisions in harmony with the guidelines. University's Office of Undergraduate Admissions should reflects a number of components in giving final admission decisions, comprising high school grades, standardized test scores, high school quality, curriculum strength, geography, alumni relationship and leadership. University's Office of Undergraduate Admissions similarly must reflect race and ethnicity. During all periods related to this lawsuit, the University has deliberated that African Americans, Hispanics and Native Americans were underrepresented minorities and it is unquestionable that the University should of course admit practically every qualified applicant from these groups"(vpcomm.umich).

\section{Conclusion}

First, in 1995/96 school year, OUA counselors evaluated applications according to grade point average and a method called SCUGA factors that entail the following applicant's high school: the strength of high school curriculum, unusual circumstances, geographical residence, and alumni relationships. Subsequently, once these scores were combined to produce an applicant's GPA, the reviewing admissions counselors followed a set of guidelines tables that itemized GPA ranges on the vertical axis and American College Test/Scholastic Aptitude Test (ACT/SAT) scores on the horizontal axis. The tables were divided into cells that consisted of several sequences of action to be used, consisting of admit, reject, delay for additional information, or postpone for reconsideration. For these years, applicants with the same GPA score and ACT/SAT score were exposed to different admissions results depending on their racial or ethnic status.

Second, in 1998 The University of Michigan changed the way students were accepted in the LS\&A program. The index was distributed linearly into groups mostly determining admissions outlooks: 100-150 (admit); $95-99$ (admit or postpone) 90-94 (postpone or admit); 75-89 (delay or postpone); 74 and below (delay or reject). The University of Michigan allotted guidelines procedures and the SCUGA point in consideration of a selection index for any applicant may possibly be scored with a max point of 150 .

Finally, every applicant that must obtained points on the basis of high school grade point average, standardized test scores, academic quality of an applicant's high school, strength or weakness of high school curriculum, in-state residency, alumni relationship, personal essay and personal achievement or leadership.

\section{References}

Curry George E, et al. The Affirmative Action Debate. Perseus Books: Reading, 1996. [WWW document] URL http://www.mus.edu/ meldrum1/action.htm

http://www.huppi.com/kargaroo/L-reversediscrimination.htm

http://www.nyu.edu/classes/jackson/social.issue/papers/AfaActGrG.html 
http://www.vpcomm.umich.edu/admissions/legal/gratz/gra-ussc-op.html

Supreme Court of the United States, Jennifer Gratz and Patrick Hamacher vs. Lee Bollinger, James J. Duderstadt and the Board of Regents of the University of Michigan. Number 02-516

Thomas J. Espenshade\& Chang Y. Chung, The Opportunity Cost of Admission Preferences in Elite Universities (Social Science Quarterly, Volume 86, Number 2,June 2005 by Southwestern Social Science Association)

White, Ronald F. Ph.D. Introduction to Affirmative Action [WWW document]. URL http://inside.msj.edu/academics/faculty/whiter/affirm.htm

URL http://www.inmotionmagazine.com/aahist.html

Garrett, Dr. Jan. (2002, May, 3). Discrimination and Affirmative Action. [WWW document]. URL http://www.wku.edu/ jan.garrett/discaffi.htm

Wilcher, Shirley (2003, October 12) Motion Magazine The History of Affirmative Action Policies, Americans for a fair chance Washington D.C. [WWW document].

Cato Policy Report. (2004, Nov/Dec). Affirmative Action: Myth or Necessity. Pg.8

American Association for Affirmative action. April 20, 2006. [WWW document]. URL http://www.affirmativeaction.org

Bailey, E. (2006, April 20). National Bureau of Education Research. [WWW document]. URL http://www.nber.org

\section{Copyright Disclaimer}

Copyright for this article is retained by the author(s), with first publication rights granted to the journal.

This is an open-access article distributed under the terms and conditions of the Creative Commons Attribution license (http://creativecommons.org/licenses/by/4.0/). 